\title{
Model Persamaan Struktural : Peran Kepemimpinan Transformasional Menuju Kinerja Karyawan dan Keterikatan Karyawan
}

\author{
Arviana Wulandari ${ }^{1}$ \\ Bambang Aviantono ${ }^{2}$ \\ Apri Parantoro ${ }^{3}$ \\ ${ }^{1}$ Prodi Manajemen, Sekolah Tinggi Ilmu Ekonomi Tribuana \\ Email : arvianawulandari@stietribuana.ac.id \\ ${ }^{2}$ Prodi Manajemen, SekolahTinggi Ilmu Ekonomi Tribuana \\ Email : bambangaviantono@stietribuana.ac.id \\ ${ }^{3}$ Prodi Teknik Informatika, Universitas Mitra Karya \\ Email : apriparantoro@umika.ac.id
}

\begin{abstract}
Abstrak
Studi ini bertugas untuk mengkonstruksi dugaan hubungan antara Pemimpinan transformasional dan keterikatan karyawan melalui variabel keterikatan karyawan di beberapa perusahaan impor jakarta utara. Data sampel yang diambil sebanyak 96 responden. Dengan menggunakan metode SEM proses pengolahan dan analisis data dilakukan. Adanya pengaruh positif antara pemimpin transformasional terhadap kinerja karyawan. Tetapi tidak terdapat bukti yang signifikan secara tidak langsung pemimpin transformasional melalui variabel keterikatan terhadap kinerja karyawan. Kata kunci: Pemimpinan Transformasional, Kinerja dan Keterikatan Karyawan
\end{abstract}

\section{PENDAHULUAN}

Keterikatan karyawan telah mendapatkan perhatian yang cukup signifikan dalam beberapa dekade terakhir, dengan banyak penelitian yang mengkonfirmasikan peran penting yang mereka mainkan dan lebih lanjut pengaruhnya kepada kinerja karyawan dan organisasi secara keseluruhan pada akhirnya. Studi ini ingin menunjukkan dugaan bahwa karyawan yang engage atau terikat lebih berkomitmen untuk memajukan organisasi mereka serta bekerja lebih baik. Dengan demikian dapat diyakini bahwa Tingkat keterikatan karyawan yang tinggi dapat menghasilkan kinerja yang lebih tinggi, Meningkatkan kinerja, dan niat ingin keluar dari perusahaan yang lebih rendah. Ketika seorang karyawan engage atau terikat, dia menyadari tanggung jawabnya dalam tujuan bisnis dan memotivasi rekan-rekannya, untuk keberhasilan tujuan organisasi. Schaufeli, dkk, menyatakan lebih lanjut bahwaketerikatan karyawan sebagai "pemenuhan keadaan pikiran terkait pekerjaan yang positif yang ditandai dengan semangat, dedikasi dan penyerapan.Dengan demikian, karyawan yang terlibat melampaui panggilan tugas untuk melakukan peran mereka dalam keunggulan. Keterikatan di tingkat individu menurut Bakker dan Demerouti dipengaruhi terutama oleh ketersediaan sumber daya pekerjaan (dukungan, otonomi, umpan balik, dll.) Dan sumber daya pribadi (ketahanan, kemanjuran diri, optimisme, dll.), Dan dipengaruhi secara negatif oleh tingkat tuntutan pekerjaan (tekanan kerja, emosional, mental dan fisik).

Kesenjangan Teori . Haider dan Riaz, (2010) mengemukakan bahwa pemimpin transformasional memainkan peran penting dalam kinerja kualitas organisasi namun tidak menyinggung masalah pentingnya keterikatan karyawan. Bushra et al., (2011) mencatat bahwa ada hubungan positif antara kepemimpinan transformasional dengan kepuasan kerja dan komitmen kerja karyawan di sektor bank dan tidak memunculkan keterikatan karyawan dalam studinya.

Studi ini mengkonstruksidugaan hubungan antara kepemimpinan transformasional dan keterikatan karyawan di beberapa perusahaan impor sejenis. Karyawan yang punya hubungan yang bagus dengan majikan mereka telah mengalami suatu perubahan atau transisi menjadi seperti terikat atau bertunangan atau engage. Meskipun demikian terdapat literatur yang terbatas di bidang ini seperti di negara berkembang Indonesia, yang pada gilirannya akan membentuk motivasi utama penelitian ini. Dalam makalah ini, fokusnya, adalah pada bagaimana memahami kepemimpinan akan berdampak pada keterikatan karyawan yang pada gilirannya akan mempengaruhi kinerja mereka. Secara khusus studi ini berfokus pada kepemimpinan transformasional, melalui proses intermediasi dari keterikatan karyawan dan bagaimana hal itu akhirnya akan mempengaruhi kinerja karyawan. 


\section{KAJIAN PUSTAKA}

Bagian dari penelitian ini bertujuan untuk meninjau literatur sistematis tentang kepemimpinan transformasional, keterikatan karyawan, dan kinerja karyawan. Karena ada banyak literatur yang tersedia tentang subjek ini. Penulis mencoba menjelaskan secara singkat konsep-konsep ini. Studi ini lebih fokus pada klarifikasi konseptual kepemimpinan transformasional, diikuti oleh peran intermediasi keterikatan karyawan dan kemudian berdampak akhir pada kinerja karyawan.

Ada penelitian besar-besaran tentang kepemimpinan karena pengaruhnya terhadap kinerja individu dan organisasi. Sarjana dari berbagai bidang studi telah melihat, dan terus melihat konsep ini dan hubungannya dengan kinerja karyawan berikutnya kepada organisasi. Namun kepemimpinan secara konseptualisasi masih terbilang bermasalah dan terlalu luas sebagai akibatnya para sarjana belum sampai pada definisi konsep yang dapat diterima secara universal. Ada banyak sekali definisi, yang terkadang membuat kebingungan di benak semua orang yang tertarik dengan subjek ini. Kepemimpinan, menurut Robbins dan Judge (2009), dapat diartikan sebagai kemampuan untuk mempengaruhi suatu kelompok menuju pencapaian suatu visi atau serangkaian tujuan (hlm. 419). Yukl G. (1999) pada bagiannya mendefinisikan kepemimpinan sebagai "proses mempengaruhi orang lain untuk memahami dan menyetujui tentang apa yang perlu dilakukan dan bagaimana melakukannya, dan proses memfasilitasi upaya individu dan kolektif untuk mencapai tujuan bersama" . Kreitner dan Kinicki (2004) mendefinisikan kepemimpinan sebagai "proses sosial di mana pemimpin mencari partisipasi sukarela dari bawahan dalam upaya untuk mencapai tujuan organisasi (hal 495). Definisi ini menyarankan komponen tertentu yang penting untuk fenomena kepemimpinan. Ini termasuk a) Kepemimpinan sebagai proses b) Kepemimpinan terjadi dalam suatu kelompok c) Kepemimpinan melibatkan mempengaruhi orang lain dan terakhir d) Kepemimpinan bertujuan untuk mencapai tujuan yang ditetapkan.

Mendefinisikan kepemimpinan sebagai proses menunjukkan bahwa kepemimpinan adalah peristiwa transaksional yang terjadi antara pemimpin dan Para pengikut mereka. Juga kepemimpinan sebagai cara untuk mempengaruhi orang lain berarti itu adalah pengalaman interaktif dua arah antara pemimpin dan pengikut daripada acara satu arah di mana pemimpin mempengaruhi pengikut dan bukan sebaliknya. Oleh karena itu kami menyimpulkan bahwa Kepemimpinan adalah proses dinamis mempengaruhi orang dengan tujuan pertemuan yang ditetapkan tujuan. Seperti yang dikatakan Rosenbloom (1998), untuk mencapai cara yang koheren menuju tujuan bersama yang disukai dalam organisasi, manajer harus berkomunikasi dengan bawahan dengan cara yang mengkomunikasikan harapan dengan jelas. Interaksi ini penting untuk kesuksesan organisasi secara keseluruhan karena mengarah pada komitmen yang lebih besar dari pihak tenaga kerja, sehingga meningkatkan motivasi, kepercayaan karyawan yang akan menumbuhkan kewarganegaraan perusahaan yang baik dan kinerja karyawan. Kepemimpinan adalah topik yang dibahas secara luas dalam literatur. Anteseden dan konsekuensinya memiliki dampak yang lebih besar pada hasil dan kinerja organisasi. Cendekiawan, seperti Hater \& Bass dan Den Hartog \& Belschak, (2012) berkontribusi dalam literatur yang menggambarkan gaya kepemimpinan transaksional dan transformasional yang menonjol. Kepemimpinan transaksional didefinisikan sebagai pertukaran penghargaan dan tujuan antara karyawan dan manajer (Howell \& Avolio, 1993). Selanjutnya, pemimpin transaksional memotivasi karyawan dengan penghargaan untuk memenuhi persyaratan Bass, (1990); Humphreys, (2002); Tajeddini, (2016). Selain itu, kepemimpinan transformasional berfokus pada pengembangan pengikut dan kebutuhan mereka. Manajer yang menerapkan gaya kepemimpinan transformasional untuk pengembangan sistem nilai karyawan yaitu motivasi dan moral (Ismail et al., 2012). Selain itu, pemimpin transformasional bertindak sebagai jembatan antara pemimpin dan pengikut untuk mengembangkan pemahaman yang jelas tentang minat, nilai, dan motivasi pengikut (Bass, 1994; Bycio et al., 1995; Tajeddini et al., 2017).

Bushra et al., (2011) mencatat bahwa ada hubungan positif antara kepemimpinan transformasional dengan kepuasan kerja dan komitmen kerja karyawan di sektor bank. Selain itu mereka menegaskan bahwa pemimpin transformasional membantu pekerja menjadi lebih kreatif dan inovatif untuk beradaptasi dengan lingkungan eksternal. Selain itu, Haider dan Riaz, (2010) mengemukakan bahwa pemimpin transformasional memainkan peran penting dalam kinerja kualitas organisasi. Selain itu, penelitian ini mengungkapkan adanya hubungan yang kuat antara kepemimpinan dan pengembangan karir. Konsekuensinya, Gumusluoglu dan Iisev, (2008) menunjukkan bahwa 
kepemimpinan transformasional memiliki pengaruh yang signifikan terhadap inovasi organisasi selama tren pasar, terutama di industri baru.

Keterikatan karyawan sebagai sebuah konsep mulai muncul dalam literatur organisasi dan bisnis sekitar dua dekade lalu dan terus ada perdebatan yang cukup besar tentang apa itu keterikatan dan bagaimana cara terbaik untuk mendefinisikannya . Para sarjana setuju bahwa keterikatan karyawan mencakup dimensi energi dan dimensi identifikasi . Banyak definisi dari para peneliti tentang keterikatan karyawan adalah kenyataan bahwa keterikatan memiliki keadaan psikologis serta keadaan emosional yang mencerminkan kesediaan mereka untuk memberikan yang terbaik dan memberikan upaya diskresioner yang berkelanjutan untuk memastikan organisasi mencapai tujuan dan kesuksesannya. .Dalam karyanya tentang keterikatan pribadi, Kahn (1990) mendefinisikan keterikatan sebagai " memanfaatkan anggota organisasi 'untuk peran pekerjaan mereka; dalam keterikatan orang mempekerjakan dan mengekspresikan diri mereka secara fisik, kognitif, dan emosional selama pertunjukan peran " (hal. 694). Sebaliknya, pelepasan melibatkan pelepasan diri anggota organisasi dari peran pekerjaan mereka. Terlibat tidak hanya secara kognitif memperhatikan pekerjaan atau perasaan dan mengekspresikan emosi positif atau melakukan pekerjaan untuk kepentingan, tetapi juga mencerminkan investasi energi kognitif, emosional dan fisik seseorang secara bersamaan dalam kinerja peran yang diberikan . Keterikatan karyawan dianggap sebagai partisipasi kognitif dan afektif dalam pekerjaan yang dilakukan dan dengan demikian ketika komplikasi muncul dalam tugas yang diberikan, hal itu dipandang baik secara positif yang mendorong keterikatan dan meningkatkan kinerja atau secara negatif yang menghasilkan ketidakpuasan dan kesusahan dan karena itu menghalangi kinerja dan bahwa keterikatan paling baik diringkas dengan seberapa positif karyawan berpikir dan merasa tentang organisasi dan juga bagaimana dia proaktif dalam kaitannya dengan pencapaian tujuan organisasi untuk pelanggan, kolega dan pemangku kepentingan lainnya. Keterikatan karyawan dengan demikian merupakan insentif non-keuangan penting yang memiliki dampak signifikan pada harmoni kerja yang harus dipastikan. Karyawan seperti itu antusias dengan pekerjaan mereka dan memiliki hubungan afektif dan energik terhadap pekerjaan tersebut daripada menganggapnya terlalu stres dan menuntut . Penelitian tentang kinerja kepemimpinan-bawahan bukanlah fenomena baru seperti yang dikemukakan oleh Fleishman dan Harris . Pengukuran hubungan antara kepemimpinan dan bawahan dan hasil mereka telah menjadi sumber diskusi yang cukup banyak. Beberapa ahli berpendapat bahwa tingkat hubungan antara pemimpin dan bawahan memang berpengaruh pada cara karyawan berperilaku, berdasarkan asumsi bahwa pemimpin mengubah perilaku mereka di antara bawahan . Menurut Mehra, dkk. ketika sebuah organisasi mencari cara yang efisien untuk itu untuk mengungguli pesaingnya, pendekatannya adalah fokus pada kepemimpinan.

Dalam setiap organisasi, hubungan interpersonal menjadi hal yang mengikat orang-orang dari semua tingkatan. Hubungan interpersonal ini ditentukan oleh keteraturan dan cara di mana interaksi terjadi antara manajer dan bawahannya . Menurut Jaatinen dan Lavikka, (2008), tantangan utama bagi pemimpin dalam mengkoordinasikan organisasinya adalah tugas harmonisasi melalui interaksi yang efektif dari para mitra. Jadi menurut perspektif manajemen hubungan, pekerjaan organisasi dipengaruhi oleh kemampuannya untuk mengembangkan hubungan yang saling memuaskan antara manajer dan karyawan Ledingham, (2003). Literatur yang ada juga menghubungkan hubungan antara manajer dan karyawan dengan komitmen karyawan, retensi karyawan dan retensi pelanggan Wilson, (2000).

Kinerja karyawan telah digunakan secara bergantian dengan prestasi kerja dalam literatur sehingga menimbulkan kesulitan dalam definisi konsep karena itu adalah "konstruksi abstrak dan laten" Viswesvaran, (2005). Campbell dkk. (1993) mendefinisikan kinerja pekerjaan sebagai "hal-hal yang dapat diamati yang dilakukan orang-orang yang relevan dengan tujuan organisasi" (314), sedangkan Viswesvaran dan Ones (2000: 216) menyatakan bahwa kinerja pekerjaan adalah "tindakan, perilaku, dan hasil yang dapat diukur bahwa karyawan terlibat atau mewujudkan yang terkait dengan dan berkontribusi pada tujuan organisasi. " Motowidlo (2003) mendefinisikan prestasi kerja "sebagai nilai total yang diharapkan untuk organisasi episode perilaku diskrit yang dilakukan seseorang selama periode waktu standar" . Namun Conway menggabungkan kinerja karyawan dan pekerjaan, dan mendefinisikannya "sebagai sejauh mana seseorang menyelesaikan tugas yang diperlukan untuk menempati posisi tertentu, yang ia asumsikan dalam sebuah organisasi"; sedangkan Armstrong (2006: 498) mengatakan itu adalah "pencapaian, pelaksanaan, pelaksanaan, mengerjakan apa pun yang 
diperintahkan atau dilakukan. Kinerja karyawan kemudian dilihat dari segi produktivitas dan output karyawan, yang mempengaruhi atau membantu organisasi menjadi efisien dan efektif dalam mencapai tujuannya: atau, sebagaimana Motowidlo et al. (1997) berpendapat, "sejauh mana seorang individu membantu organisasi mencapai tujuannya" .

Hipotesa penelitian ini dikonstruksikan sebagai berikut:

H1 : Terdapat pengaruh antara Kepemimpinan Transformasional terhadap Kinerja Karyawan Bass, B. M. (1985). Buil, I., Martínez, E., \& Matute, J. (2019).

H2 : Terdapat pengaruh antara Pemimpinan Transformasional terhadap Keterikatan Karyawan Paul Tristen Balwant, Rehaana Mohammed, Riann Singh (2019).

H3 : Terdapat pengaruh antara Keterikatan Karyawan terhadap Kinerja Karyawan Azmi Azizah and Aurik Gustomo (2015)

Penulis berupaya memvisualisasikan Kerangka Berpikir Penelitian seperti dibawah ini :

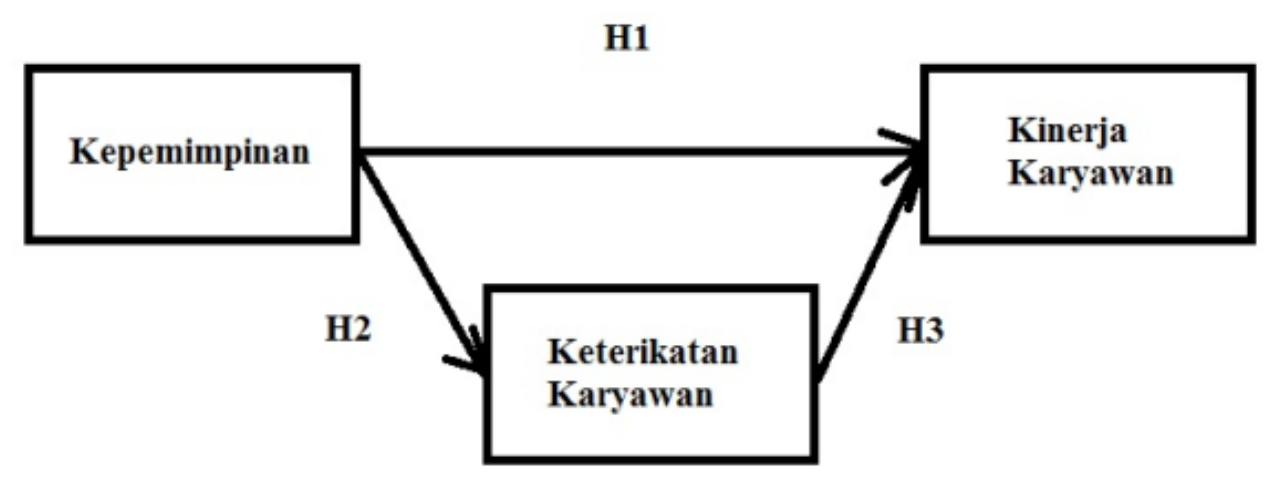

Gambar tersebut menjelaskan dimana kepemimpinan diduga berpengaruh kepada kinerja karyawan secara langsung, dan juga melalui variabel antara keterikatan karyawan.

\section{METODOLOGI PENELITIAN}

Rencana Kegiatan penelitian dilakukan di 3 perusahaan berbasis industri impor. Wilayah mencakup area sekitar Jakarta Utara. Dimana waktu penelitian dilakukan pada bulan januari 2020.

Ruang Lingkup Penelitian dibatasi hanya pada soal kepemimpinan, kinerja karyawan dan keterikatan karyawan atau biasa dikenal dengan employee engagement.

Definisi Variabel Operasional Kepemimpinan Transformasional dengan melibatkan beberapa dimensi yang cukup sering diusulkan oleh banyak peneliti seperti 1. Motivasi yang mengispirasi 2. Pengaruh idealisasi 3. Stimulasi intelektual 4. Pertimbangan individu.

Definisi Variabel Operasional Kinerja Karyawan telah merujuk kepada beberapa dimensi seperti: 1. Jumlah Outputyang diukur dari banyaknya keluaran kerja yang dihasilkan sesuai dengan standar, hasil kerja yang lebih baik, dan jumlah kesalahan yang diminimalisir. 2. Kualitas Outputyang diukur dari mutu hasil kerja sesuai dengan standar yang ditetapkan, dengan melihat ketepatan, ketelitian, kerapihan, dan keberhasilan hasil pekerjaan sesuai yang di harapkan 3. Nilai Tambah Output diukur dari kesenjangan atau gab input output kerja 4. Ketepatan Waktu diukur dari kesesuaian pelaporan 5. Kehadiran diukur dari frekuensi kehadiran kualitatif.

Definisi Variabel Operasional Keterikatan Karyawan dalam penelitian ini merupakan perwujudan dari hasil skor kuesioner Keterikatan Karyawan melalui pengukuran jawaban responden. Adapun beberapa dimensi yang akan dipergunakan dalam penelitian ini adalah 1. Vigor diukur dengan tingkat energi, keikhlasan. 2. Absorbsi diukur dengan totalitas, komitmen. 3. Dedikasi diukur rasa bangga, inspirasi, menantang.

Sampel dan Tekhnik Pengumpulan Data. Untuk jumlah sampel sebesar 100 responden diambil dengan menggunakan metode slovin atas populasi yang telah ditentukan sesuai area penelitian. 
Sistem Skala data yang dipergunakan dengan menggunakan skala likert pada sistem wawancara langsung melalui penggunaan kuesioner berupa kumpulan pertanyaan tertutup. Jawaban setiap item instrumen yang menggunakan skala likert mempunyai gradasi dari sangat positif sampai sangat negatif, yang dapat berupa kata-kata, Sugiyono, (2013). Untuk Keperluan analisis kuantitatif, maka jawaban dari penelitian itu dapat diberi skor, misalnya:

1. Sangat Setuju

2. Setuju

3. Cukup Setuju

4. Tidak setuju

5. Sangat tidak setuju diberi skor 5

diberi skor 4

diberi skor 3

diberi skor 2

diberi skor 1

Yang kemudian akan dilakukan pengembangan instrument penelitian.

Validasi Pengukuran dilakukan melalui beberapa proses filter statistik deskriptif dan inferensial. Model Persamaan Struktural melalui analisis outer loading, inner loading, penetapan model persamaan struktural dan yang terakhir adalah penentuan analisis jalur. Perangkat lunak yang dipergunakan adalah SMART PLS 3.0.

\section{HASIL DANPEMBAHASAN}

Bagian ini menyajikan temuan penelitian.

\begin{tabular}{|c|c|c|c|}
\hline \multicolumn{4}{|c|}{ Outer Loadings } \\
\hline \multicolumn{4}{|l|}{ 圂 Matrix } \\
\hline & Kepemimpinan & Keterikatan Karyawan & Kinerja Karyawan \\
\hline EP1 & & 0.783 & \\
\hline EP2 & & 0.830 & \\
\hline EP3 & & 0.776 & \\
\hline KK1 & & & 0.921 \\
\hline KK4 & & & 0.876 \\
\hline KK5 & & & 0.951 \\
\hline $\mathrm{KP} 1$ & 0.998 & & \\
\hline KP4 & 0.998 & & \\
\hline
\end{tabular}

Dari tabel diatas menunjukkan bahwa semua indikator berada diatas $>0.7$ loading factor-nya sehingga bisa dikatakan bahwa seluruh indikator telah merefleksikan dengan baik variabel latennya dan juga menunjukkan validitas konvergen yang bisa diterima.

Validitas dan Reliabilitas Konstrak

\begin{tabular}{|c|c|c|c|c|c|c|c|c|}
\hline \multicolumn{9}{|c|}{ Construct Reliability and Validity } \\
\hline \multirow[t]{2}{*}{ Matrix } & 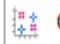 & Cronbach's Alpha & 期革 rho_A & 淦 $\mathrm{H}$ & aposite Reliability & 接莘 & Average Variance Extracted (AVE) & \\
\hline & & \multicolumn{2}{|c|}{ Cronbach's Alpha } & rho_A & \multicolumn{2}{|c|}{ Composite Reliability } & \multicolumn{2}{|c|}{ Average Variance Extracted (AVE) } \\
\hline \multicolumn{2}{|c|}{ Kepemimpinan } & \multicolumn{2}{|c|}{0.996} & 0.996 & \multicolumn{2}{|c|}{0.998} & \multicolumn{2}{|c|}{0.996} \\
\hline \multicolumn{2}{|c|}{ Keterikatan Kar... } & \multicolumn{2}{|c|}{0.712} & 0.712 & \multicolumn{2}{|c|}{0.839} & \multicolumn{2}{|c|}{0.635} \\
\hline \multicolumn{2}{|c|}{ Kinerja Karyawan } & \multicolumn{2}{|c|}{0.904} & 0.906 & \multicolumn{2}{|c|}{0.940} & \multicolumn{2}{|c|}{0.839} \\
\hline
\end{tabular}

Tabel diatas menunjukkan status data yang reliabel ditunjukkan oleh parameter cronbach alpha lebih besar dari 0.7 begitu juga diperkuat oleh parameter composite $>0.7$ dan memiliki validitas yang baik dimana status AVE diatas 0.5 untuk bisa dilanjutkan kedalam analisis outer atau inner model. 


\section{Analisis Outer Model}

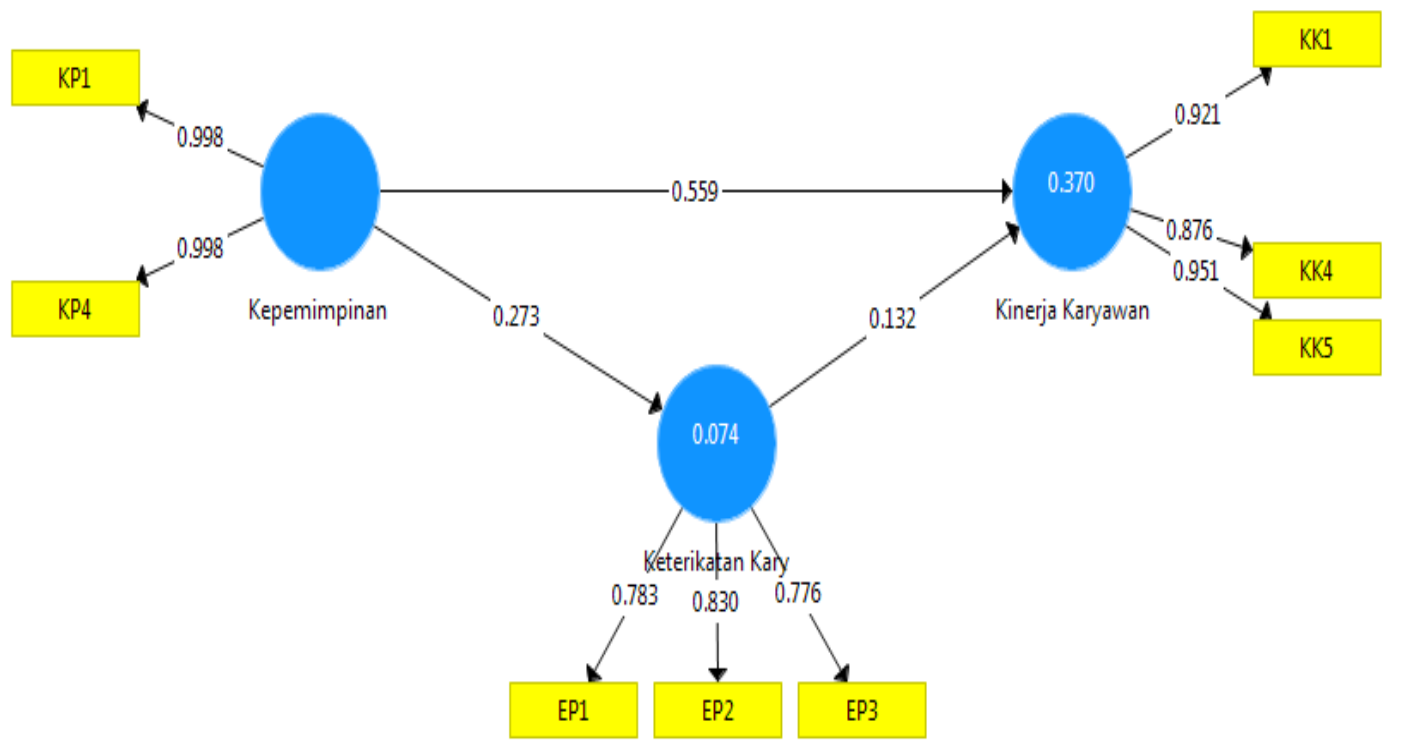

Sebenarnya analisis outer model telah ditunjukkan oleh semua loading factor yang telah merefleksikan semua variabel laten dengan baik. Dengan demikian dapat dikatakan bahwa didalam penelitian ini analisis outer model sudah menyimpulkan dengan baik model yang ditawarkan oleh penulis. Walaupun memang pada saat proses data, ada sekitar 5 indikator yang terpaksa di drop atau dihapus, hal ini dilakukan demi tercapainya keadaan status model fit yang terbaik.

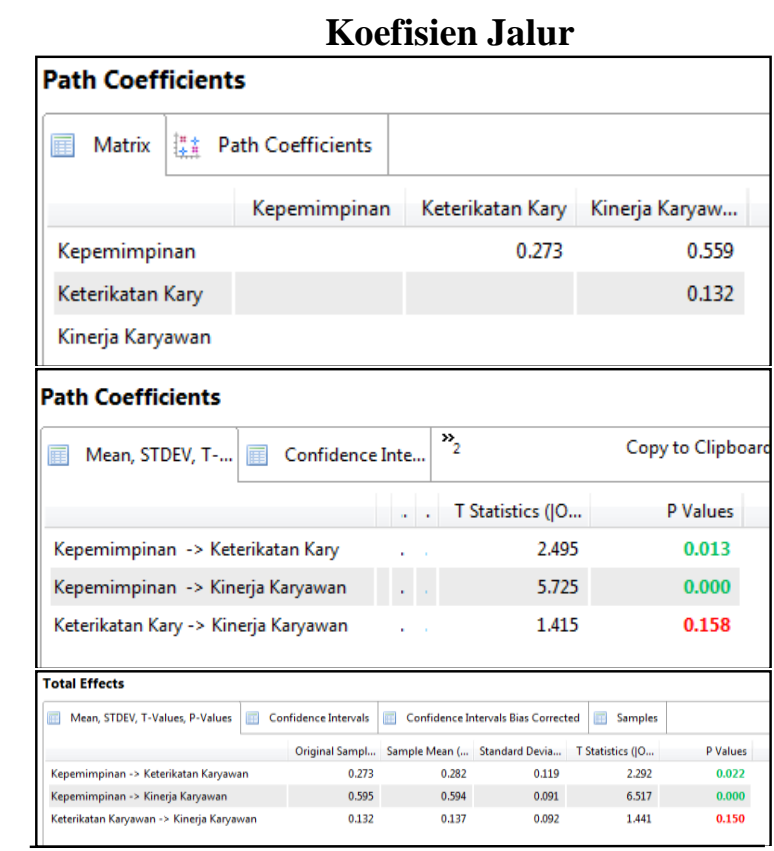

Persamaan Struktural 1

$\mathrm{KK}=0.559 \mathrm{KP}+0.132 \mathrm{KTK}$

Persamaan Struktural 2

$\mathrm{KTK}=0.273 \mathrm{KP}$ 
Terlihat bahwa persamaan struktural pertama menjelaskan pengaruh KP atau Kepemimpinan sebesar 0.56 dan KTK atau Keterikatan karyawan sebesar 0.132. Sedangkan persamaan struktural ke 2 menunjukkan pengaruh kepemimpinan kepada kepada KTK atau Keterikatan karyawan sebesar 0.273 dengan kekuatan pengaruh tidak terlalu besar namun terbukti signifikan. Hubungan pengaruh keterikatan karyawan kepada kinerja karyawan tidak terbukti berpengaruh secara signifikan maka dapat disimpulkan bahwa pengaruh tidak langsung antara kepemimpinan kepada kinerja karyawan melalui variabel intermediasi keterikatan kerja menjadi gugur atau tidak terbukti secara signifikan.

Total Pengaruh

\begin{tabular}{|l|l|l|l|}
\hline Variabel & Langsung & $\begin{array}{l}\text { Tak } \\
\text { Langsung }\end{array}$ & Total \\
\hline KP>KK & $\mathbf{0 . 5 5 9}$ & $\mathbf{0 . 0 3 6}$ & $\mathbf{0 . 5 9 5}$ \\
\hline KTK $>$ KK & $\mathbf{0 . 1 3 2}$ & & $\begin{array}{l}\text { Tidak } \\
\text { valid }\end{array}$ \\
\hline Total & Pengaruh & & 0.595 \\
\hline
\end{tabular}

Dari hasil analisis inner model maka ditemukan hasil pengaruh total sebesar 0.595 dari variabel kepemimpinan transformasional kepada kinerja karyawan dan hal ini sekaligus menjawab dimana letak tingkat kekuatan model yang tergolong moderat dalam memprediksi seluruh mekanisme transmisi atas model persamaan struktural diatas.

\begin{tabular}{|c|c|c|c|c|}
\hline \multicolumn{5}{|c|}{ R kuadrat dan Model Fit } \\
\hline \multicolumn{5}{|l|}{ R Square } \\
\hline \multirow[t]{2}{*}{ Matrix } & 掉章 & R Square & 掉童 R & Square Adjusted \\
\hline & & & R Square & R Square Adjus... \\
\hline \multicolumn{2}{|c|}{ Keterikatan Kary } & & 0.074 & 0.064 \\
\hline \multicolumn{2}{|c|}{ Kinerja Karyawan } & & 0.370 & 0.357 \\
\hline \multicolumn{5}{|l|}{ Model_Fit } \\
\hline \multirow[t]{2}{*}{ Fit Sum } & mary & rms & Theta & \\
\hline & & Saturated & d Model & Estimated Mo... \\
\hline \multicolumn{2}{|l|}{ SRMR } & & 0.069 & 0.069 \\
\hline \multicolumn{2}{|l|}{ d_ULS } & & 0.171 & 0.171 \\
\hline \multicolumn{2}{|l|}{ d_G } & & 0.166 & 0.166 \\
\hline \multicolumn{2}{|l|}{ Chi-Square } & & 103.990 & 103.990 \\
\hline \multicolumn{2}{|l|}{ NFI } & & 0.860 & 0.860 \\
\hline
\end{tabular}

Variabilitas laten kepemimpinan mampu menjelaskan lebih baik langsung kepada kinerja karyawan sebesar R2 37\%, namun kurang begitu kuat penjelasannya kepada variasi perubahan dari keterikatan kerja atau hanya sebesar $7.4 \%$ saja.

Lebih lanjut ditemukan bahwa secara umum parameter yang ditunjukkan oleh informasi model fit Smart PLS dalam keadaan baik dan mampu diterima sebagai prasyarat model yang cukup baikdimana NFI 0.860 .

Dari hasil studi ini didapati bahwa peran pengaruh kepemimpinan transaksional dalam mempengaruhi secara langsung keterikatan kerja dan kinerja karyawan sangat berarti. Hal tersebut berimplikasi luas pada hubungan antar karyawan di perusahaan. Jika seorang pemimpin mampu memberikan pengaruh yang positif baik secara motivasi positif maupun negatif terhadap kondisi hubungan antar karyawan dengan demikian bisa dipastikan bahwa keterikatan karyawan akan meningkat yang akhirnya berperan terhadap seluruh key performance index manajeman dan kinerja karyawan. 


\section{KESIMPULAN}

Kesimpulan pada penelitian ini menunjukan bahwa kemampuan pemimpin untuk mempengaruhi suatu kelompok menuju pencapaian suatu visi atau serangkaian tindakan harus ditingkatkan, kepemimpinan sebagai proses mempengaruhi orang lain untuk memahami dan menyetujui tentang apa yang perlu dilakukan dan bagaimana melakukannya merupakan proses yang harus dilalui sehingga setiap mekanisme bisa berperan mempengaruh semangat kerja dan suasana kerja positif. Begitu juga dalam hal memfasilitasi upaya individu dan kolektif untuk mencapai tujuan bersama memberikan mekanisme yang positif membangun energi yang positif baik mental kognitf serta attitude terhadap keterikatan karyawan sehingga diharapkan bisa berlanjut kepada perbaikan kinerja karyawan secara integral. Kepemimpinan juga sebagai proses sosial di mana pemimpin mencari partisipasi sukarela dari bawahan dalam upaya untuk mencapai tujuan terbukti mampu membangun setiap sisi parameter index kinerja karyawan secara langsung.

\section{REFERENCES}

\section{Journal}

Beck, Aaron T. (1993). Cognitive Therapy: Past,Present, and Future. Jurnal of Consulting and Clinical Psychology. Vol 61: 194-198. Ali, S. H. K., Khan, N. S., \& Yildiz, Y. (2020). Leadership effects on CSR employee, media, customer, and NGOs. Management and Economics Research Journal, 6, 1-9.

Azmi Azizah and Aurik Gustomo.School of Business and Management Institut Teknologi Bandung, Indonesia azmi.azizah@sbm-itb.ac.id The influence of employee engagament to employee performance at pt telkom bandung.. Journal of business management Vol. 4, No.7, 2015: 817829

Altun, M. (2019). The Effect of Extra-Curricular Activities in Hizmet Movement Schools on Students' Personal Growth: A Case Study in Kurdistan Region, Iraq. International Journal of Academic Research in Business and Social Sciences, 9(2), 203-210.

Armstrong. 2006. A handbook of Human Resource Management Pract Ice. Tenth edition published by Kogan

Bass, B. M. (1985). Leadership and performance beyond expectations. New York, Free Press.

Bass, B. M., \& Avolio, B. J. (1994). Transformational leadership and organizational culture. The International Journal of Public Administration, 17(3-4), 541-554. Budur, T. (2018a). Analytic Hierarchy Process to Evaluate Corporate Image, Trust, and Switching Cost of GSM Operators: A Case of Kurdistan Region of Iraq. International Journal of Social Sciences \& Educational Studies, 5(2), 241-250

Budur, T. (2018b). The impact of Al-Ghazali's virtues on organizational commitment and performance: A case Study at private education institutions in Kurdistan Region of Iraq. Icabep, Erbil-Iraq, 2, p21.

Budur, T., \& Demir, A. (2019a). Leadership Effects on Employee Perception about CSR in Kurdistan Region of Iraq. International Journal of Social Sciences \& Educational Studies, 6(1), 142-154.

Budur, T., \& Demir, A. (2019b). Leadership Perceptions Based on Gender, Experience , and Education Leadership Perceptions Based on Gender, Experience, and Education. International Journal of Social Sciences \& Educational Studies, 6(1), 142-154.

Budur, T., Faraj, K. M., \& Karim, L. A. (2019). Benchmarking operations strategies via hybrid model : A case study of café-restaurant sector. Amazonia Investiga, 8(23), 842-854.

Budur, T., Rashid, C. A., \& Poturak, M. (2018). Students Perceptions on University Selection, Decision Making Process: A Case Study in Kurdistan Region of Iraq. International Journal of Social Sciences \& Educational Studies, 5(1), 133-144.

Buil, I., Martínez, E., \& Matute, J. (2019). Transformational leadership and employee performance: The role of identification, engagement and proactive personality. International Journal of Hospitality Management, 77, 64-75. 
Burns, J. (1978). Leadership. New York, NY: Harper \& Row.

Bushra, F., Ahmad, U., \& Naveed, A. (2011). Effect of transformational leadership on employees' job satisfaction and organizational commitment in banking sector of Lahore (Pakistan). International Journal of Business and Social Science, 2(18), 261-267.

Bycio, P., Hackett, R. D., \& Allen, J. S. (1995). Further assessments of Bass's (1985) conceptualization of transactional and transformational leadership. Journal of Applied Psychology, 80(4), 468.

Demir, A., Shawkat, S., Majeed, B.N., Budur, T. (2019). Fuzzy AHP and VIKOR to select best location for bank investment: Case study in Kurdistan Region of Iraq. In Effective investments on capital markets, Tarczyn'sk W, Nermend K (eds). Springer: Cham; 485-510.

Demir, A. (2019). A benchmarking of service quality in telecommunication services: Case study in Kurdistan Region of Iraq. International Journal of Social Sciences \& Educational Studies, 5(3), 216-231. Demir, A., \& Budur, T. (2019). Roles of leadership styles in corporate social responsibility to non-governmental organizations (NGOs). International Journal of Social Sciences \& Educational Studies, 5(4), 174-183.

Den Hartog, D. N., \& Belschak, F. D. (2012). When does transformational leadership enhance employee proactive behavior? The role of autonomy and role breadth self-efficacy. Journal of Applied Psychology, 97(1), 194.

Dinc, M. S., \& Aydemir, M. (2014). Ethical leadership and employee behaviours: an empirical study of mediating factors. International Journal of Business Governance and Ethics, 9(3), 293-312.

Fleishman, E. A., \& Harris, E. F. (1962). Patterns of leadership behavior related to employee grievances and turnover. Personnel Psychology, 15(2),

Hater, J. J., \& Bass, B. M. (1988). Superiors' evaluations and subordinates' perceptions of transformational and transactional leadership. Journal of Applied Psychology, 73(4), 695.

Howell, J. M., \& Avolio, B. J. (1993). Transformational leadership, transactional leadership, locus of control, and support for innovation: Key predictors of consolidated-business-unit performance. Journal of Applied Psychology, 78(6), 891.

Humphreys, J. H. (2002). The Anabasis and lessons in leadership: Xenophon as a prototypical transformational leader. Journal of Management Research, 2(3), 136-146.

Ismail, A. M., Reza, R., \& Mahdi, S. (2012). Analysis the relationship between cultural intelligence and transformational leadership. International Journal of Business and Social Science, 3(14), 252-261.

Khan, N. U. S., \& Yildiz, Y. (2020). Impact of Intangible Characteristics of Universities on Student Satisfaction. Amazonia Investiga, 9(26), 105-116.

Kreitner, R., \&Kinicki, A. (2004). Organizational behavior. Boston, MA: McGraw- Hill Irwin.

MacKenzie, S. B., Podsakoff, P. M., \& Rich, G. A. (2001). Transformational and transactional leadership and salesperson performance. Journal of the Academy of Marketing Science, 29(2), 115.

Madhu, B., \& Krishnan, V. R. (2005). Impact of transformational leadership and karma-yoga on organizational citizenship behavior. Prestige Journal of Management and Research, 9(1), 1-20.

McCleskey, J. A. (2014). Situational, transformational, and transactional leadership and leadership development. Journal of Business Studies Quarterly, 5(4), 117.

Mohammed, S. S., Suleyman, C., \& Taylan, B. (2020). Burnout determinants and consequences among university lecturers. Amazonia Investiga, 9(27), 13-24.

Motowidlo, S.J., \& Beier, M. E. (2010). Differentiating specific job knowledge from implicit trait policies in procedural knowledge measured by a situational judgment test. Journal of Applied Psychology, 95 
Robbins, Stephen P. \& Timothy A. Judge. 2009. Organizational Behavior. 13 ThreeEdition, USA: Pearson International Edition, Prentice -Hall.

Paul Tristen Balwant, Rehaana Mohammed, Riann Singh Transformational leadership and employee engagement in Trinidad's service sector: The role of job resources.2019.International Journal of Emerging Markets.

Tajeddini, K. (2015). Using the integration of disparate antecedents to drive world-class innovation performance: An empirical investigation of Swiss watchTajeddini, K. (2016). Analyzing the influence of learning orientation and innovativeness on performance of public organizations: The case of Iran, Journal of Management Development, 35(2), 134-153.

Tajeddini, K.,Walle,A.H., \& Denisa, M., (2017). Enterprising women, tourism, and development: The case of Bail. International Journal of Hospitality \& Tourism Administration, 18(2), 195-218.

Torlak, N. G., \& Kuzey, C. (2019). Leadership, job satisfaction and performance links in private education institutes of Pakistan. International Journal of Productivity and Performance Management, 68 (2), 276-295. https://doi.org/10.1108/IJPPM-05-2018-0182

Torlak, N. G., Demir, A., \& Budur, T. (2019). Impact of operations management strategies on customer satisfaction and behavioral intentions at café-restaurants. International Journal of Productivity and Performance Management. https://doi.org/10.1108/IJPPM-01-2019-0001

Ones D S \& Viswesvaran C (1998a) Gender, age and race differences on overt integrity tests: results across four large-scale applicant data sets. Journal of Applied Psychology, 83

Sugiyono. (2010). Statistik untuk Pendidikan. Bandung: Alfabeta.

Sugiyono. (2011). Metode Penelitian Kombinasi. Bandung: Alfabeta

Sugiyono. (2012). Metode Penelitian Kuantitatif Kualitatif Dan R\&D. Bandung: Alfabeta.

Yildiz, Y., \& Budur, T. (2019). Introducing Environmental Awareness to College Students with Curricular and Extracurricular Activities. International Journal of Academic Research in Business and Social Sciences, 9(3), 666-673.

Yukl, G. (1999). An evaluation of conceptual weaknesses in transformational and charismatic leadership theories. Leadership Quarterly, 10(2), 285-305. https://doi.org/10.1016/S10489843(99)00013-2 